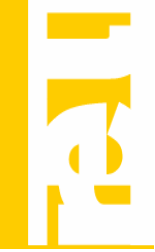

\title{
Unions, Temporary Employment and Hours of Work: A Tale of Two Countries
}

\author{
Marco Francesconi* and Carlos García-Serrano ${ }^{\dagger, 1}$ \\ * University of Essex, UK. ${ }^{\dagger}$ Universidad de Alcalá, Spain
}

Received 17 October 2003; accepted 14 June 2004

\begin{abstract}
This paper is the first attempt to analyse the relationship between unionisation, temporary employment and non-standard hours of work, comparing Spain and Britain, which are characterised by relatively different labour market structures and substantially different degrees of employment protections. Despite such differences, these two countries show similar responses of unionisation to flexible employment. In particular, we find that union recognition in Britain and firm-level union presence in Spain do not respond to changes in long hours of work and overtime hours, whereas temporary employment is negatively correlated with union coverage in both countries. We find, however, some differences between the two countries when the samples are stratified by industry.
\end{abstract}

Keywords: Collective bargaining, trade unions, temporary employment, hours of work JEL Classification: J22, J23, J51, J53

\footnotetext{
${ }^{1}$ Author for correspondence:carlos.garcia@uah.es Part of this study has been supported by the UK Economic and Social Research Council under "The Future of Work: Flexible Employment, Part-time Work and Career Development in Britain" Award No.L212 25 2007, and by the British Council and the Ministry of Education under the "Acciones Integradas" Award HB98-60 for collaborative pilot research projects. The Spanish data were provided by the Social and Labour Statistics Office from the Spanish Ministry of Labour and Social Affairs. We thank María Teresa Giráldez for her permission to use the Spanish dataset. We are grateful to Alison Booth for helpful discussions on this topic and comments on an earlier draft and to two anonymous referees for their suggestions to improve the paper.
}

(C) Revista de Economía Laboral 


\section{Introduction}

In the past two decades there has been an unabated decline in union membership and union recognition in many industrialised economies (Storey and Bacon, 1993; Deery and Walsh, 1999; Machin, 2000; Farber and Western, 2000). At the same time, some commentators have emphasised a sharp rise in "non-standard" types of employment (e.g., parttime and fixed-term employment), with an increased interest in labour market flexibility in public policy debates (OECD, 1999 and 2002). ${ }^{2}$

In this paper we investigate the relationship between unionism and two non-monetary characteristics of employment that policy makers have increasingly used with the aim of achieving higher levels of labour market flexibility, namely temporary employment and number of hours of work. This relationship is relevant to analysts as well as policy makers but has been rarely explored. ${ }^{3}$ Indeed, the two characteristics that are of interest here are important because one, temporary employment, is likely to affect the "extensive margin" (through the number of people who are to be employed in temporary jobs) and the other, hours of work, practically defines the "intensive margin" (see Heckman, 1993).

We perform our analysis by comparing the relationships of interest in two labour markets as different as those of Spain and Great Britain. In Spain almost 70 percent of workers are covered by some form of collective bargaining during the 1990s (OECD, 1997), whereas union coverage involves only 47 percent of British workers during the period 1993-1997 (Cully and Woodland, 1998). Interestingly, union membership is greater in Britain than in Spain: an average of 31 percent over the period 1989-1997 for Britain versus no more than 10 percent for Spain. These two countries are also different in terms of labour market "flexibility", as measured by temporary employment and hours of work. Between 1985 and 1997, the proportion of workers on fixed-term contracts tripled in Spain - going from 11 to 33 percent - but remained fairly stable in the UK - from 7 to 7.4 percent (European Commission, 1999). Conversely, as of 1997, the British labour market is characterised by a fraction of part-time workers that is three times greater than that in the Spanish labour market, 25 percent versus 8 percent. Similarly, a greater fraction of British employees work

\footnotetext{
2 Specific studies on the extent of flexible employment include, among others, Dex and McCulloch (1995) and Booth et al. (2002) for Britain and Dolado et al. (2002) for Spain. None of these studies describes the relationship between flexible employment and unionisation.

${ }^{3}$ An exception is the study by Booth and Francesconi (2003), which, however, looks only at Britain and, crucially, misses all the element of cross-national comparison.
} 
Unions, Temporary Employment and Hours of Work

more than 48 hours per week as compared to their Spanish counterparts: almost 20 percent (during 1991-1997) versus 6 percent (in 1997), respectively.

Another reason for performing this cross-national comparison is that the differing institutions in each country - namely the degree of employment protection - allow us to examine different features of flexible work. Britain provides the case where weak employment protection means that the outcome follows an essentially unregulated market. Spain is the opposite extreme, whereby a strict employment protection legislation influences both regular and flexible work. ${ }^{4}$

The substantial (but differently distributed) presence of flexible employment in these two countries and the different degrees of employment protection pose new relevant questions about the role played by trade unions in each economy. Is union coverage more likely to expand over the extensive margin, involving temporary forms of employment? Or is it more likely to expand over the intensive margin, recruiting people in "non-standard" hours jobs? Or, on the contrary, is it more likely to fade away for all types of non-standard employment and exclusively rely on the core of permanent regular workers? Do the institutional and historical differences between the Spanish and British labour markets shed any light in unpacking the relationship of unionism with worked hours and temporary work?

We address these questions using two different data sources. For Britain, we use a large representative sample of workers from the British Household Panel Survey (BHPS), collected annually during the period 1991-1997. For Spain, we use the census of firms with more than 500 employees derived from the Encuesta de Coyuntura Laboral (ECL) or Survey of Economic Situation, collected quarterly in 1993-2001. During this period, the macroeconomic environment is relatively similar for both Spain and Britain, with both economies going through a recovery and an expansion after a recession which bashed the two countries at the beginning of the 1990s. Both countries are clearly characterised by different levels of economic activity, GDP per capita, rates of inflation and unemployment. But the dynamic patterns of these and other macroeconomic indicators are somewhat comparable over the 1990s (European Commission, 1999). This means that different levels of macroeconomic aggregates or different positions over the business cycle are not likely to explain the relationships of interest for this paper.

\footnotetext{
${ }^{4}$ A detailed account of employment protection legislation in the European Union over the 1986-1997 period can be found in Fondazione Rodolfo De Benedetti (2000).
} 
Controls for country-specific macroeconomic conditions are nonetheless included in our empirical analysis to account for such differences.

One point should be clarified at the outset. Although they both are panels, the BHPS and the ECL collect different data with distinct sampling procedures. As explained in the next sections, we adopt definitions of union status, temporary employment and part-time employment that differ in the two countries. Likewise, the aspects of workers' or firms' characteristics that are controlled for in the econometric analysis are also different by country. These differences notwithstanding, the two datasets used in this study do provide the appropriate pieces of information for the issue of interest. In fact, the main goal of our crosscountry comparison is to sketch a first longitudinal account on how the degree of unionisation in Britain and Spain is associated with specific nonmonetary characteristics of (intensive and extensive margins of) employment. While we have some understanding of the relationship between unionism and flexible work for each separate country, much less is known on whether the employment relations in one economy at a point in time are specific to that county or share some fundamental characteristics with the employment relations in another economy with a very different labour market. Our paper aims to fill (at least part of) this gap.

The remainder of this paper is organised as follows. Section 2 provides the theoretical background to our analysis. In Section 3, we outline the most salient aspects of the institutional settings related to unionism, temporary employment and hours of work in Spain and Britain. Section 4 presents the country-specific data used in estimation and defines our measures of unionism, temporary employment and hours of work. Section 5 presents the benchmark estimates obtained from multivariate regression analyses for the two countries, extends these results to account for unobserved heterogeneity exploiting the longitudinal nature of our data, and discusses additional estimates obtained after stratifying the sample by broad industrial categories. Section 6 summarises our main conclusions.

\section{Theoretical background}

Trade unions have been historically regarded as a key player in the labour market, organising workers, embodying the conflict of interest between employers and workers and also providing a means of resolution of this conflict (Lewis, 1991). For most of the past century, collective 
bargaining has been the principal mode of governance of the employment relationship. In general, collective bargaining emerged when there were rents to be shared with employers, and where the workforce had the power to induce the firms to share in any surplus (Booth, 1995).

Now, to the extent that temporary employment involves marginal jobs in marginal firms - where there are limited rents to be shared and employees are in a weak bargaining position through the nature of the employment contract - temporary workers will be less likely to be covered by a union for collective bargaining. Perhaps the very attractiveness for firms and policy makers of some types of non-standard employment (including part-time and temporary work) is that workers in such jobs have little bargaining power and thus the costs of possible conflict resolutions are negligible. We expect therefore that coverage by collective bargaining will be lower amongst temporary workers and workers with relatively short time schedules, because they are in a weaker bargaining position and are harder to organise than workers in permanent full-time jobs (Booth and Francesconi, 2003).

The "voice" theory, proposed by Hirschman (1970) and developed by Freeman and Medoff (1979) and Freeman (1980), argues that workers' voice is embodied in unionism and the collective bargaining system to negotiate with management. If unions improve working conditions and provide a voice for workers' job dissatisfaction, then their presence is likely to be associated with better job matches, fewer quits and longer job tenure. ${ }^{5}$ Under these advantageous circumstances, unionised firms may find it easier than non-unionised firms to face temporary (positive) demand shocks by adjusting working hours and not by changing (increasing) the level of employment. ${ }^{6}$

Unions, however, may be more willing to exploit a sustained economic growth in terms of higher levels of permanent employment

\footnotetext{
${ }^{5}$ From the predictions of the specific human capital literature, we also expect that such longer and more stable worker-firm pairs involve investment sharing in firm-specific training. This, in turn, further reduces turnover of trained labour (Becker, 1962; Parsons, 1972).

${ }^{6}$ Hamermesh (1993) argues that, in response to a temporary shock, firms take longer to adjust their employment than their total hours for given employment. Furthermore, unionised firms face greater fixed employment costs relative to variable employment costs than do non-union firms (Booth, 1995). Where there are substantial fixed costs associated with hiring and firing workers, we would expect to observe firms changing hours of work of a given number of employees (rather than changing the number of employees working a given number of hours) in response to small demand fluctuations. But if the demand fluctuations are large, unions may have a preference for an employment expansion over hours increases.
} 
rather than an increased number of working hours for a given number of workers. It may also be the case that people who work particularly long hours feel they will achieve more on the basis of individual effort rather than through collective union strategies. Therefore, if unions prefer employment expansions over hours-of-work increases, and/or long hours of work signal greater work effort (Landers et al., 1996), then we expect a negative correlation between unionism and long hours of work. It remains therefore an empirical issue as to which one of these two opposite correlations dominates.

In analysing the relationship of collective bargaining with temporary and part-time employment and long-hours jobs, there are two other important elements to consider. First, a number of European Union (EU) initiatives have been recently introduced with the aim of improving the working conditions of traditionally weak groups of the workforce, particularly part-timers (e.g., the 1998 EU Directive on Working Time) and temporary workers (e.g., the 1999 EU Directive on Fixed-term Work). These initiatives, to which Britain and Spain have already complied at different degrees at the times of their introduction, might act as a substitute for union activity, for they provide the employment protection that otherwise unions would negotiate. In addition, the presence of statutory minimum wages may be regarded as a substitute for another union activity, that of collectively bargained wages. ${ }^{7}$ If both types of policy initiatives affect non-standard workers more than they affect standard workers, we may expect to observe a negative association of the level of unionisation with some forms of non-standard employment, such as temporary and part-time employment.

The second important element is given by the open attempt of unions to recruit non-standard workers, particularly in Britain (Heery et al., 2000), in response to the relentless decline in union presence through the 1980s and 1990s and the increasing proportion of new union-free workplaces (Machin, 2000). If this "strategy of enlargement" is successful, then non-standard workers (the new union recruits) and standard workers (the traditional union base) are likely to experience similar levels of unionisation. At this point, however, it is not clear how this expected

\footnotetext{
${ }^{7}$ In Spain, the minimum wage, the so-called salario mínimo interprofesional, dates back from the early 1960s and is set by the government in consultation with trade unions and employers' associations. See Dolado et al. (1996) and Dolado et al. (1997). In Britain, the national minimum wage was introduced on 1 April 1999 (outside our sample period), even though it was one of the manifesto commitments of the Labour Party. Since the Labour Party's victory of the general election on 1 May 1997, firms, workers and trade unions had almost two years to adjust their behaviour and expectations before its actual implementation.
} 
enlargement will spread across different types of non-standard employment, that is, which workers will first be recruited and which ones will be harder to cover by union contracts. It is also not clear (and, given the sample period of our data, probably early to evaluate) how this strategy will be affected by the above-mentioned policy initiatives. ${ }^{8}$

We are not in this paper able to estimate the impact of such initiatives on the union coverage of non-standard workers, since their potential effects would have occurred after the end of our sample period in both Spain and Britain. However, we would emphasise that it is important to chart the extent of union coverage across non-standard work before their implementation, because this allows us to establish a benchmark against which the effect of such changes can be evaluated. Furthermore, the presumably larger institutional differences that characterised Britain and Spain before the introduction of the EU regulations (see the next section), may allow us to investigate how unions have differently succeeded in expanding their coverage of workers engaged in nonstandard employment over the 1990s.

\section{Overview of the institutional settings}

In this section, we describe the key characteristics of the industrial relations system in Spain and Britain, addressing the differences between them. In particular, we discuss the salient institutional features concerning unionism - especially the level at which bargaining occurs and the extent of coordination - temporary employment, and hours of work.

\subsection{Unionism}

As mentioned in the Introduction, the distinction between union density or membership (the proportion of wage and salary workers who are union members) and union coverage (the proportion of wage and salary workers covered by a collective bargaining agreement) is not trivial in our context. In Spain, union membership has been declining over time and was relatively low at about 10 percent in the mid-1990s, whereas coverage remains high and affects a large fraction of the workforce (almost 70 percent). In the UK, during the same time period, the corresponding figures are 39 and 47 percent (OECD, 1994 and 1997). ${ }^{9}$

\footnotetext{
8 Booth and Francesconi (2003) find virtually no evidence of unions' enlargement to British non-standard workers during the 1990s.

${ }^{9}$ Disney et al. (1994) and Machin (2000) document the sharp decline in the presence of and the role played by unions in Britain. They point to the failure to organise the new
} 
Among the several forms of bargaining that may occur, three are relevant for this study. There is single-employer bargaining between trade unions and individual firms/plants, multi-employer bargaining (industry or region wide) between union federations and employer associations, and national wage agreements between trade union confederations, central employer organisations and government. Notice that these three levels of bargaining are not mutually exclusive given multilevel bargaining. ${ }^{10}$ It can be argued that British unions follow an American model in which firm/plant bargaining dominates, while Spanish unions follow a continental European model in which sectoral and regional bargaining dominates ${ }^{11}$.

There are two striking features of British collective bargaining during the 1990s. First, not only is the dominant form of trade unionism a de facto "enterprise unionism" in which unions organise and represent workers at the level of the employing enterprise or firm. But the system of collective employment law also reinforces this pattern by effectively licensing firm-level union representation (Booth, 1995; Heery et al., 2000). Second, the erosion of influence of collective bargaining has been accompanied by the rise of employment contracts, which - for most employees - have become both highly standardised and increasingly formalised. Moreover, where trade unions retain recognition, their influence has become more narrow and consultative. In particular, union activity is associated with superior non-pay terms and conditions and with greater access to statutory rights compared with organisations where trade unions are weak or absent (Brown, 1999).

In Spain, industry-level bargaining between the representative employer association and worker associations results in sectoral agreements whose geographical scope might be the whole nation but is usually the province or the region. Firm-level bargaining between employer and worker representatives may act as a substantial supplement to the sectoral/regional agreements, while national economy-wide bargaining was only used in the 1980s. A distinctive feature of the Spanish Labour Law is the erga omnes principle. This ensures the ex-ante application to every worker of the conditions settled by the parties in the collective bargaining at each level. For example, in the province-sectoral level an agreement between unions and firms' representatives will affect all workers in every firm from that industry in that province. ${ }^{12}$

establishments in the last twenty years as one of the major causes of this decline.

${ }^{10}$ A review of the nature of bargaining in the early 1990s can be found in OECD (1994).

11 For a description of the legal environment of the Spanish labour market and the industrial relations system, see Jimeno and Toharia (1993) and Escobar (1995).

${ }^{12}$ In other European countries, there are some similar legal principles but they usually 
Importantly, the parties (and not the Government) decide the level of bargaining. Trade unions and the main representative employer association (CEOE) encourage sectoral and national level agreements where their ability to impose organizational objectives is greater than at the firm/plant level. ${ }^{13}$ At this level there can be two non-mutually exclusive types of workers' representatives: the union sections (secciones sindicales) and the works councils (comités de empresa). The works councils, which can only exist in firms with 50 employees or more, have gained a high reputation among workers since the early 1980s. Although both these institutions can coexist in the bargaining process at the firm level, there is evidence of a greater role played by works councils (GarcíaMurcia et al., 1995; Escobar, 1995).

The erga omnes principle naturally creates a labour market where all workers are de facto covered by unions. However, employment adjustment decisions that are specific to a particular firm - such as decisions over temporary work and overtime hours - may affect firms differently depending on whether they have firm/plant level rather than sectoral/regional level collective bargaining. Indeed, at the former level, those decisions are directly shared by the employer and the workers' representatives (union sections or works councils). At the latter level, unions and employers reach an agreement without necessarily taking into account specific conditions at the firm level. Therefore, since the majority of collective agreements at the firm/plant level is initiated by works councils (above 80 percent, according to Garcia-Murcia et al., 1995), we assume that the existence of this sort of agreement is a proxy variable for a stronger organised action of workers' representatives (see subsection 4.1). ${ }^{14}$

Finally, in relation to the degree of coordination, Britain can be classified as a country with no coordination since there is a predominance of firm- and plant-level bargaining (OECD, 1994). This has become increasingly apparent in the 1980s and has continued into the 1990s in

apply ex-post.

13 There is also evidence of some topics specialization by levels (among others, see Jimeno, 1992). Bargaining at the sectoral level is mostly about wages and working hours. Firm-level bargaining (in large firms) is more detailed and includes issues such as absenteeism and productivity, but explicit bargaining over employment is rarely observed.

${ }^{14}$ A major reform took place in 1994 that altered the labour relations system in Spain. One of its basic features was to strenghten collective agreements, since they assumed more functions. In particular, the reform tried to give more relevance to firm-level agreements in an attempt to bring nearer to the firms' scope issues demanding a more particular treatment. 
response to the increased competition in the product and labour markets and to the sharp rise of deregulatory policies, with the growing pressure of employers for decentralised bargaining or no bargaining at all. ${ }^{15}$ In the case of Spain, instead, coordination is explicitly institutionalised in the bargaining system at the different bargaining levels. Results from all levels constitute a hierarchical order of collective agreements where lowlevel agreements try to complement high-level agreements.

\subsection{Temporary employment and hours of work}

Despite the rapid growth of several forms of non-standard employment in Britain during the last two decades (Dex and McCulloch, 1995), temporary employment involves only a small fraction of the British workforce. In the period between 1991 and 1997, about 7 percent of men and 10 percent of women were employed in some types of temporary jobs (Booth et al., 2002). ${ }^{16}$ Perhaps as a consequence of the small number of workers involved or, most likely, as an outcome of the pervasive deregulation of the labour market which took place during the 1980s, the institutional restrictions on temporary employment are relatively minimal. In particular, the initial use of temporary contracts is not limited in any specific way, there is no restriction on the maximum number of successive contracts before the employment relation is terminated or the contract becomes permanent, and there is also no specified restriction on the maximum total duration of successive temporary contracts. The 1999 EU Directive on Fixed-term Work provides the only institutional framework to regulate temporary employment in Britain (Department of Trade and Industry, 2001), but this falls outside our sample period. ${ }^{17}$

Outside our sample period falls also the (proposed) legislation to regulate hours of work and part-time employment (under the $1998 \mathrm{EU}$ Directive on Working Time and the 2000 UK Government's Regulations

15 Brown et al. (2000) date the legal roots of individualisation in British employment relations back to the 1960s, rather than the 1980s and 1990s. In that earlier period, in fact, the enactment of statutory employment protection rights began to revive the individual contract of employment as a focus for and instrument of employment regulation.

16 These figures exclude students, self-employed and people aged more than 60 .

17 The main objectives of the directive are fairly modest, anyway. They are centered around the principle of "no-less-favorable" treatment of temporary employees than comparable permanent employees, with the introduction of measures to prevent abuse of temporary contracts arising from successive renewals and to inform temporary workers of vacancies and opportunities in their organisation on the same basis of their permanent counterparts. Interestingly, these regulations do not cover pay and pension benefits. 
on the Prevention of Less Favourable Treatment for Part-time Workers, respectively). However, up to 1997 (the last available year for the British data), the institutional restrictions on both hours of work and part-time employment are rather limited. This is quite surprising given that a large fraction of British employees report long hours of work and overtime hours, and a significant proportion of women are employed in part-time jobs (Dex, 1999; Booth and Francesconi, 2003). An exception is represented by the 1996 Employment Rights Act, which ensures a wide range of rights and protections to all employees, including protection of wages, Sunday working, maternity rights, redundancy payments and unfair dismissals. But its implementation has been ineffective towards most types of non-standard workers, as its revamp through the 2000 Parttime Workers Regulations underlines.

The institutional picture is very different in the case of Spain. Spanish firms have increasingly used fixed-term contracts since a change in employment legislation took place at the end of 1984, which was aimed at increasing labour market flexibility. The change in the law permitted temporary contracts to be used for reasons other than the temporary nature of the job. In fact, under the 1984 Employment Promotion Programme, there was the possibility to renew some fixed-term contracts up to three years. After that period of time on a fixed-term contract in the same firm, continued employment meant that the worker became permanent. In the case of termination of the contract, the same worker could not be reemployed by the same firm under the same sort of employment relationship until one year had passed. The aim of the reform was that firms could adjust employment more easily without having to change separation rules for workers on permanent contracts, thus avoiding (or reducing) exceptionally high firing costs and rigid employment protection rules. The result was that the proportion of wage and salary workers with temporary contracts increased from less than 10 percent in the mid-1980s to around 33 percent in the early 1990s, without marked gender differences. Since then, the proportion has remained stable for a decade.

But the reform of the Workers' Charter in 1994 limited the use of fixed-term contracts to three specific groups of workers: people over the age of 45, long-term unemployed receiving unemployment benefits, and disabled workers. Following this change, fixed-term contracts have clearly changed in nature and their number has declined. This reduction appears to have been compensated by "other" temporary contracts (e.g., "per task" contracts and "service" contracts).

Regarding the number of hours, the Spanish legislation allows collective bargaining agreements or labour contracts to establish the 
duration of the workweek. It also requires that the maximum duration of the normal workweek is 40 hours of average "effective work" in annual calculation. Regarding the workday, it must never exceed 9 hours, except for alternative distributions of working time agreed by collective bargaining. As for overtime, the Workers' Charter limits the number of overtime hours to 80 per worker and year, and they are forbidden for workers below 18 years of age and during the night (from 10 p.m. to 6 a.m.).

In sum, the two economies are characterised by substantially different labour market institutions regulating hours of work and overtime work as well as part-time and temporary employment. On the one hand, Britain offers an example of a highly unregulated labour market, whose trade unions play a relatively minor role in the design and implementation of the most relevant institutional mechanisms which affect the extensive and intensive margins of employment. Spain, on the other hand, has a strongly regulated labour market, with unions shaping the institutional framework of the market, either directly through negotiations or indirectly through the attempt of firms of avoiding costly employment protection legislation.

\section{Data and methods}

\subsection{Spain: Encuesta de Conyuntura Laboral (ECL)}

The data used to analyse Spain come from the Encuesta de Coyuntura Laboral (ECL) or Survey of Economic Situation. This is a nationally representative survey of Spanish establishments that have been interviewed on a quarterly basis since the second quarter of $1990 .^{18}$ The ECL samples firms stratified on the number of employees per establishments. Although the survey collects information on all firms, including those with fewer than 500 workers, our empirical analysis is based only on the sub-sample of establishments with 500 or more employees from the first quarter of 1993 to the first quarter of 2002 , for

\footnotetext{
18 The ECL covers non-agriculture industries and excludes the public administration, defence and social security, diplomatic delegations, and international and religious organisations from the service sector. The data refer mainly to single-establishment firms and multiple-establishment firms that report separately information for the subordinate units. It is possible, however, that some multiple-establishment firms combine all information on subordinate units into a single record. A detailed description of this data source can be found in the Spanish Ministry of Labour and Social Affairs website, http://www.mtas.es.
} 
Unions, Temporary Employment and Hours of Work

which the ECL is almost a census. ${ }^{19}$ In any given quarter over the sample period, these establishments represent around 15 percent of total nonagriculture employment. ${ }^{20}$ In our analysis, we have 34,379 firm-quarter observations for 2,387 different firms (an average of almost 15 observations per establishment).

Table 1a: Distribution of union coverage by temporary employment and hours of work - Spain (ECL data)

\begin{tabular}{|c|c|c|c|c|}
\hline & All & Union & $\begin{array}{l}\text { Non- } \\
\text { union }\end{array}$ & $\begin{array}{c}t \text {-test } \\
\text { of } \\
\text { difference }\end{array}$ \\
\hline Union coverage & 0.415 & & & \\
\hline Temporary employment & $\begin{array}{l}0.263 \\
(0.306)\end{array}$ & $\begin{array}{l}0.139 \\
(0.195)\end{array}$ & $\begin{array}{l}0.352 \\
(0.339)\end{array}$ & $-67.296^{* * * *}$ \\
\hline Part-time employment & $\begin{array}{l}0.082 \\
(0.167)\end{array}$ & $\begin{array}{l}0.043 \\
(0.118)\end{array}$ & $\begin{array}{l}0.109 \\
(0.190)\end{array}$ & $-36.296^{* * *}$ \\
\hline $\begin{array}{l}\text { Proportion of firms doing } \\
\text { overtime }\end{array}$ & $\begin{array}{l}0.550 \\
(0.498)\end{array}$ & $\begin{array}{l}0.742 \\
(0.437)\end{array}$ & $\begin{array}{l}0.414 \\
(0.493)\end{array}$ & $63.652^{* * * *}$ \\
\hline Overtime hours (conditional) & $\begin{array}{l}23.4 \\
(81.49)\end{array}$ & $\begin{array}{l}21.4 \\
(22.15)\end{array}$ & $\begin{array}{l}25.9 \\
(120.23)\end{array}$ & $-3.711^{* * * *}$ \\
\hline $\begin{array}{l}\text { Proportion of workers working } \\
\text { overtime (conditional) }\end{array}$ & $\begin{array}{l}0.277 \\
(0.264)\end{array}$ & $\begin{array}{l}0.294 \\
(0.245)\end{array}$ & $\begin{array}{l}0.254 \\
(0.285)\end{array}$ & $10.340^{* * * *}$ \\
\hline Female employment & $\begin{array}{l}0.381 \\
(0.255)\end{array}$ & $\begin{array}{l}0.247 \\
(0.216)\end{array}$ & $\begin{array}{l}0.477 \\
(0.238)\end{array}$ & $-92.016^{* * *}$ \\
\hline$N$ & 34,379 & 14,276 & 20,103 & \\
\hline
\end{tabular}

Note: "Union coverage" takes value of unity if firm has collective bargaining at the firm/plant level. The term "Union" applies to firms with collective bargaining at the firm/plant level; "Non-union" applies to firms with collective bargaining at the sector/industry/province level. The column labelled " $t$ test of difference" reports the value of the $t$ statistic for the average difference in union and non-union rates. $N$ is number of firm-quarter observations.

$* * *$ significant at 0.01 level.

19 Our selection is dictated by a practical reason. In the first quarter of 1997 , there has been a major procedural change in the collection/distribution of the ECL data, so that the Spanish Ministry of Labour and Social Affairs was favourable to provide data only for that firm size group. Notice, however, that the establishments which had 500 or more employees as of 1993-I are part of our sample, regardless of whether their workforce had subsequently fallen below that threshold or not. Furthermore, large establishments that answered the questionnaire in some but not all of the quarters of the period 1993-2002 have also been included in our sample.

20 This employment share is consistent with that coming from other data sources. For instance, the Structure, Consciousness and Class Biography Survey (Encuesta de Estructura, Conciencia y Biografía de Clase, ECBC), carried out in 1991, shows that the employment share of private firms with 1,000 employees or more was 10 percent. 
The ECL data allow us to distinguish between firms with firm/plant level collective bargaining and firms with higher (e.g., industry, sector, province) bargaining level. As argued in subsection 3.1, our assumption is that the existence of a firm/plant level agreement is a good proxy for union activities directly organised by workers' representatives. ${ }^{21}$ Table 1a reports the distribution of this measure of unionisation among establishments and the means of temporary employment and hours of work by union status. Nearly 42 percent of establishments have firm/plant level agreements (i.e. they are characterised by an organised action of workers' representatives). About 26 percent of all workers in the sampled firms are on a temporary contract, while only 8 percent are employed in a part-time job. Notice also that 55 percent of the establishments use overtime work, with (conditional) averages of 23 hours of overtime per worker in a quarter and 28 percent of employees working overtime.

Table 1a also documents the extent to which temporary and parttime employment and overtime work are distributed across union and non-union establishments. Temporary and part-time employment are significantly more common among non-union plants: the proportion of workers with temporary contracts (in part-time employment) is only 14 percent ( 4 percent) in union plants, but 35 percent (11 percent) in nonunion firms.

On the contrary, the use of overtime work is significantly more common among union plants: not only is the proportion of union firms using overtime higher (74 percent) compared to non-union firms (41 percent), but also the (conditional) proportion of individuals working overtime is larger (29 percent versus 25 percent). However, the resulting conditional average of overtime hours is slightly lower in union firms (21 hours versus 26 hours per worker and quarter).

Therefore, union firms seem to give priority to the intensive margin, with a strong emphasis on the measures of overtime work, whereas our two components of the extensive margin (part-time and temporary employment) are clearly concentrated in non-union firms. ${ }^{22}$ Finally, to allow for some comparison with the British sample, in which we distinguish between men and women, we also look at how the proportion of female employment is related to unionisation. The raw data

${ }^{21}$ In subsequent sections of the paper, we may sometimes refer to this as 'union coverage' or 'unionisation' for expositional convenience.

22 To the extent that part-timers are not working shorter hours only when firms require it (that is, part-timers and full-timers are complements), part-time employment does not affect the intensive margin directly. We will adopt this interpretation also in the analysis of the British data (see below). 
Unions, Temporary Employment and Hours of Work

show that women are significantly more concentrated in non-union plants (48 percent) than in union plants (25 percent).

\subsection{Great Britain: British Household Panel Survey (BHPS)}

The data used to analyse Britain come from the first seven waves of the British Household Panel Survey (BHPS), collected between 1991 and 1997. This is a nationally representative random sample survey of private households in Britain, which have been annually interviewed since the autumn of $1991 .^{23}$ Our analysis is based on the sub-sample of men and women who were born after 1936 (thus aged at most 60 in 1997), who reported positive hours of work, who provided complete information at the interview dates, who left school and were employed at the time of the survey, and who were not in the armed forces or self-employed. These selection criteria lead to a longitudinal sample of 1,728 men and 1,971 women, with 11,186 and 12,821 person-wave observations, respectively. ${ }^{24}$

Table 1b: Distribution of union coverage by temporary employment and hours of work - Britain (BHPS data)

\begin{tabular}{|c|c|c|c|c|c|c|c|c|}
\hline & \multicolumn{4}{|c|}{ Men } & \multicolumn{4}{|c|}{ Women } \\
\hline & $A l l$ & Union & $\begin{array}{l}\text { Non- } \\
\text { union }\end{array}$ & $\begin{array}{c}t \text {-test } \\
\text { of difference }\end{array}$ & All & Union & $\begin{array}{l}\text { Non- } \\
\text { union }\end{array}$ & $\begin{array}{c}t \text {-test } \\
\text { of difference }\end{array}$ \\
\hline Union coverage & 0.547 & & & & 0.507 & & & \\
\hline Temporary employment: & & & & & & & & \\
\hline Seasonal/casual & 0.039 & 0.025 & 0.055 & $-8.100 * * *$ & 0.063 & 0.042 & 0.085 & $-10.033^{* * *}$ \\
\hline Fixed-term contract & 0.029 & 0.028 & 0.031 & -0.955 & 0.033 & 0.044 & 0.022 & $6.884^{* * * *}$ \\
\hline $\begin{array}{l}\text { Permanent employment } \\
\text { Hours of work: }\end{array}$ & 0.932 & 0.947 & 0.914 & $6.836^{*-* * *}$ & 0.904 & 0.914 & 0.893 & $4.079^{* * * *}$ \\
\hline$<16$ hours a week & 0.028 & 0.013 & 0.046 & $-10.774^{* * * *}$ & 0.150 & 0.093 & 0.210 & $-18.691^{* * * *}$ \\
\hline 16-29 hours a week & 0.018 & 0.015 & 0.022 & $-2.929^{* * * *}$ & 0.228 & 0.216 & 0.241 & $-3.279^{* * * *}$ \\
\hline$>48$ hours a week & 0.288 & 0.250 & 0.339 & $-9.836^{* * *}$ & 0.071 & 0.079 & 0.063 & $3.390 * * *$ \\
\hline $\begin{array}{l}\text { Standard hours (30-48 a } \\
\text { week) }\end{array}$ & 0.666 & 0.723 & 0.594 & $14.088^{* * * *}$ & 0.550 & 0.612 & 0.486 & $14.376^{* * * *}$ \\
\hline$N$ & 11,186 & 6,121 & 5,065 & & 12,821 & 6,502 & 6,319 & \\
\hline
\end{tabular}

23 A detailed description of the data source, its sampling scheme, weighting and imputation procedures provided to account for differential unit non-response, the questionnaire and the variables can be found at http://www.iser.essex.ac.uk/bhps/doc/index.htm.

${ }^{24}$ On average, this amounts to six repeated observations per individual over the seven years of the survey. 
Table $1 \mathrm{~b}$ reports the distribution of union coverage for men and women. ${ }^{25}$ Approximately 55 percent of men and 51 percent of women are in union-covered jobs. The 4-point difference is statistically significant and, as in Spain, reveals a greater likelihood of women to be in non-union jobs. The data allow us to identify two types of temporary employment, that is, seasonal/casual work and work done under contract or for a fixed period of time. In terms of hours of work, we distinguish between those who work 1 to 15 hours per week ("mini-jobs"), those who work between 16 and 29 hours per week and those who work more than 48 hours per week. ${ }^{26}$ The table shows that only 7 percent of men and 10 percent of women are in temporary employment, while 33 percent of men and 45 percent of women are in jobs involving non-standard hours. Notice, however, that almost 29 percent of men work long hours and 38 percent of women work less than 30 hours per week. ${ }^{27}$

In addition, the table shows how temporary and non-standardhour employment are distributed across union and non-union workers. For men, all types of temporary employment (except for fixed-term contracts) and non-standard hours employment are significantly more common among non-union workers. For example, of those who are nonunion workers, about 6 percent have seasonal/casual jobs while this proportions is only 3 percent for union-covered workers. Of those who are not covered, 34 percent work long hours while the proportion is 25 percent for union-covered workers. In the case of women, the differences between union and non-union workers are always significant, but non-standard employment is not always more prevalent in the non-union sector. In fact, larger proportions of union-covered women are on fixed-term contracts and work more than 48 hours a week.

\footnotetext{
25 These figures are statistically identical to those obtained with weighted data, which account for attrition and item non-response in the first seven waves of the BHPS. For the sake of brevity, the statistics using weighted data are not reported.

26 The choice of these cutoffs is motivated by current institutional settings in Britain. Workers in mini-jobs (and low income) are potentially eligible for the Income Support and Jobseeker's Allowance benefits (Iacovou and Berthoud, 2000). Those working between 16 and 29 hours are comparable to those in "half-time jobs" defined in Hakim (1997). Those working long hours (48 or more) are the target of recent EU policy initiatives (such as the 1998 European Working Time Directive) that aim to reduce the number of hours worked in a week below 48 (Neathey and Arrowsmith, 1999).

${ }^{27}$ In interpreting our regression results, we assume that workers who work more than 48 hours a week affect the intensive margin directly, whereas, to the extent that hours of work are downward-inelastic for full-timers, those working less than 30 hours a week are assumed to affect the extensive margin only.
} 
Unions, Temporary Employment and Hours of Work

\subsection{Methods of estimation and explanatory variables}

For both Spain and Britain, we perform our multivariate analysis using cross-sectional and panel probit regressions of union recognition on temporary employment and hours of work. From our discussion in Section 3 and from Tables $1 \mathrm{a}$ and $1 \mathrm{~b}$, it is clear that not only is the definition of union coverage different between the two countries, but also the definitions of temporary and part-time employment and hours of work differ. In addition, because of the different sampling schemes and data availability, also the other explanatory variables included in the econometric models are different. For both samples we tried to achieve the most satisfactory representation of the data after experimenting with several different potential determinants of unionisation. The definitions and means of these variables are reported in Appendix Table A1.

The analysis for Britain is carried out separately for men and women (we have also performed some estimations for the total) and controls for: years of experience in part-time and full-time work, age groups (4 dummy variables), cohort of entry in the labour market (5), disability status, marital status (3), number of children by age group (the two child's age groups are: 0-4 years of age and 5-16 years of age), educational qualification (6 dummy variables), region of residence (7), house tenure (3), industry (10), occupation (9), sector (5), firm size (4), and the ratio of the local unemployment to local vacancies (which proxies macroeconomic conditions). In the estimations, we have included not only personal characteristics (which are meant to capture individual preferences and restrictions) but also job and firm characteristics (since union recognition may vary according to the nature of the job held, the workplace conditions and the type of firm for which the individual is working).

The regressions performed on the ECL data include the characteristics of the firms' workforce (proportions of temporary and parttime employment, of women, and of workers working overtime) and controls for: firm size, quarterly GDP changes, and dummy variables for strike activity, time trend (10 dummy variables), industry (10) and labour market reform (1). Both GDP changes and time trend dummy variables are meant to capture the conditions of the macroeconomy. The industry dummies are included as important predictors for the probability of a firm having either a firm-level or a higher-level (sectoral/ regional) collective agreement. The dummy variable on labour market reform is intended to capture the possible consequences for the Spanish labour relations system of the reform that took place in $1994 .{ }^{28}$

${ }^{28}$ However, this variable is never statistically significant in the regressions presented in 


\section{Results}

\subsection{Benchmark estimates}

Tables 2 and 3 report the results for Spain and Britain, respectively. Both tables show the marginal effects (and absolute $t$-ratios) obtained from pooled probit regressions - i.e., regressions performed on the entire set of firm-quarter or person-wave observations - of the probability of an establishment having firm/plant-level union recognition (Spain) or the probability of a worker being in a job which is covered by a collective bargaining agreement (Britain). ${ }^{29}$ The tables only report the results for the variables capturing the various forms of non-standard employment for the two countries. The estimates of the other explanatory variables are not reported for brevity (but can be obtained from the authors upon request). The first row of each table reports the baseline probability of having firm-level union recognition or being in a unioncovered job, evaluated at the means of the corresponding samples. Adding or subtracting the marginal effects from such baseline probabilities provides the overall effect of the corresponding variable.

For Spain, Table 2 reports the results from three different specifications. The difference between specifications (1) and (2) is that they separately include the number of overtime hours and the proportion of workers doing overtime, while specification (3) includes both variables and their interaction. Regardless of the specification, the larger the proportion of temporary employment, the lower the probability for a given plant of having a firm-specific union agreement. This effect is however small. The reduction in the baseline probability is of about 0.4 percentage points. In any case, the most active type of unionisation is negatively associated with this non-standard component of the employment extensive margin.

Results on overtime variables, which more closely define the intensive margin, are more complex. The joint effects of the three overtime variables in specification (3) provide a different picture than that obtained from the raw data in Table 1a. For instance, an increase in the average overtime work by one hour a week, for a given (average) proportion of workers doing overtime, increases the probability of a firm to have firmspecific union agreements only slightly by one-tenth of a percentage point $(=0.0001-0.004 \times 0.277)$. But if both overtime hours and the proportion of workers working overtime change simultaneously, then a unit increase in

section 5 .

${ }^{29}$ All the marginal effects are calculated as the derivative of the conditional expectation of the observed dependent variable, and evaluated at the sample means, following the procedure in Greene (1997). 
both variables (one extra hour in overtime hours and one extra percentage point in the proportion of workers working overtime) leads to a reduction in the probability of union coverage by two-tenths of a percentage point $(=0.0001+0.002-0.004)$. Thus, at least according to specification (3), also expansions over the intensive margins are likely to be negatively associated with unionisation.

Table 2: Estimated marginal effects of temporary employment and hours of work on the likelihood of union coverage - Spain

\begin{tabular}{|c|c|c|c|}
\hline & \multicolumn{3}{|c|}{ Specification } \\
\hline & (1) & (2) & (3) \\
\hline Baseline probability & 0.402 & 0.403 & 0.403 \\
\hline Temporary employment & $\begin{array}{l}-0.004^{* * * *} \\
(29.48)\end{array}$ & $\begin{array}{l}-0.004^{* * * *} \\
(29.89)\end{array}$ & $\begin{array}{l}-0.004^{* * * *} \\
(29.52)\end{array}$ \\
\hline Part-time employment & $\begin{array}{l}0.0002 \\
(0.90)\end{array}$ & $\begin{array}{l}0.0004^{*} \\
(1.74)\end{array}$ & $\begin{array}{l}0.0004^{*} \\
(1.73)\end{array}$ \\
\hline Overtime hours & $\begin{array}{l}-0.0004 \\
(0.81)\end{array}$ & - & $\begin{array}{l}0.0001 \\
(1.76)\end{array}$ \\
\hline $\begin{array}{l}\text { Proportion of workers working } \\
\text { overtime }\end{array}$ & - & $\begin{array}{l}0.0007 * * * \\
(5.18)\end{array}$ & $\begin{array}{l}0.002^{* * *} \\
(9.59)\end{array}$ \\
\hline $\begin{array}{l}\text { Overtime hours } \times \text { Proportion of } \\
\text { workers working overtime }\end{array}$ & - & - & $\begin{array}{l}-0.004^{* * *} \\
(8.34)\end{array}$ \\
\hline Female & $\begin{array}{l}-0.007 * * * \\
(38.03)\end{array}$ & $\begin{array}{l}-0.006^{* * *} \\
(39.22)\end{array}$ & $\begin{array}{l}-0.007 * * * \\
(36.60)\end{array}$ \\
\hline Log likelihood & $-16,723.8$ & $-16,688.5$ & $-16,650.4$ \\
\hline Model $\chi^{2}$ & $\begin{array}{l}13,219.4 \\
{[0.000]}\end{array}$ & $\begin{array}{l}13,205.4 \\
{[0.000]}\end{array}$ & $\begin{array}{l}13,281.6 \\
{[0.000]}\end{array}$ \\
\hline$N$ & 34,378 & & \\
\hline
\end{tabular}

Note: Obtained from probit regressions. $N$ is number of firm-quarter observations. Absolute $t$-values are reported in parentheses. The $t$-ratios are computed using standard errors that are robust to arbitrary forms of heteroskedasticity. Model $\chi^{2}$ is the Wald statistic for the goodness-of-fit test and is equal to $-2\left(\mathrm{~L}_{\mathrm{R}}-\mathrm{LU}\right)$ where $\mathrm{L}_{\mathrm{R}}$ is the constant-only log-likelihood value and $\mathrm{LU}_{\mathrm{U}}$ is the log-likelihood value reported in the table. Its corresponding $\mathrm{p}$-value is reported in square brackets. The $\chi^{2}$ has 25 degrees of freedom in specifications (1) and (2), and 27 in specification (3). All specifications also include: firm size, quarterly GDP change, and dummy variables for strike activity, time trend (10 dummies), industry (10), labour market reform (1) and a constant.

$* * *$ significant at 0.01 level, ** significant at 0.05 level, * significant at 0.10 level

Table 3 reports the results for Britain for the full sample and by gender. It also provides them for a subsample of individuals working in firms with at least 500 employees, in an attempt to make the comparison with the Spanish dataset more reasonable. Workers on non-standard (seasonal/casual and fixed-term) contracts are highly heterogeneous 
(Booth et al., 2002). So, we may expect relevant differences amongst them. Both types of temporary employment are negatively correlated to union coverage: a seasonal/casual job decreases the union coverage probability by 10 points (from 53 to 43 percent), while a fixed-term contract reduces this probability by almost 8 points. These effects are larger in the case of women (in particular, the effect of having a seasonal/casual job) and even larger for workers in large firms (especially the effect of having a fixedterm contract). However, for men being employed in a seasonal/casual job has no significant impact on the union coverage probability, and those on fixed term contracts are 7 percentage points less likely to be union covered than the base of permanent men (although this effect is significant only at the 10 percent level).

Consider now the union effects over the intensive margin. For both men and women and for workers in large firms, union recognition tends to be strongly (positively) associated with jobs characterised by regular hours. The effects are similar in magnitude for the full sample, for men and women, and for the subsample of workers in large firms. Relative to the base of 30-48 hours of work, having a mini-job - working less than 16 hours a week - reduces the probability of union recognition by about 16 percentage points for both men and women. Similarly, working more than 48 hours a week is associated with a significant reduction in the probability of union coverage by around 9 percentage points. It is interesting that there is no statistical difference in the union coverage probability for men and women (and for workers in large firms) between those working 30-48 hours and those in half-jobs (who work 16-29 hours a week).

In sum, despite the profound differences in the institutional settings of the labour markets between Spain and Britain, unionisation and flexible employment show some similar patterns of correlation in both countries. Spanish firms that use a larger fraction of temporary workers and British workers on temporary contracts are significantly less likely to be in the union sector. This finding is in line with the theoretical arguments outlined in Section 2. Furthermore, part-time employment is not clearly negatively associated with union coverage in both countries, either for Spanish firms or for half-time workers in Britain, who show the same probability of union recognition as workers in regular-hour jobs.

A lower probability of union coverage characterises the intensive margin at the top of the hours distribution too. Spanish firms using overtime work and workers doing overtime hours as well as British workers working for more than 48 hours a week have a significantly lower probability of being covered by (firm-specific, in the case of Spain) collective bargaining agreements. Even though the magnitude of the 
country-specific effects is different, these results are quite striking. How much this is the outcome of the cross-sectional nature of the estimates presented in Tables 2 and 3 rather than a genuine effect will be partly investigated in the next sub-section. But it is nonetheless interesting that we find a similar picture for two countries with such different degrees of employment protection and different compositions of the workforce in flexible employment.

Table 3: Estimated marginal effects of temporary employment and hours of work on the likelihood of union coverage - Britain

\begin{tabular}{|c|c|c|c|c|}
\hline & $\begin{array}{c}\text { All } \\
\text { (men and } \\
\text { women) }\end{array}$ & Men & Women & $\begin{array}{l}\text { Workers in } \\
\text { firms with } \\
500+\text { empl. }\end{array}$ \\
\hline Baseline probability & 0.526 & 0.563 & 0.518 & 0.786 \\
\hline Seasonal/casual & $\begin{array}{l}-0.099 * * * \\
(3.982)\end{array}$ & $\begin{array}{l}-0.043 \\
(1.080)\end{array}$ & $\begin{array}{l}-0.155^{* * *} \\
(4.947)\end{array}$ & $\begin{array}{l}-0.163^{* * * *} \\
(3.447)\end{array}$ \\
\hline Fixed-term contract & $\begin{array}{l}-0.075^{* *} \\
(2.479)\end{array}$ & $\begin{array}{l}-0.074^{*} \\
(1.668)\end{array}$ & $\begin{array}{l}-0.090 * * \\
(2.132)\end{array}$ & $\begin{array}{l}-0.269 * * * \\
(5.820)\end{array}$ \\
\hline$<16$ hours a week & $\begin{array}{l}-0.186^{* * * *} \\
(7.147)\end{array}$ & $\begin{array}{l}-0.156^{* * * *} \\
(2.781)\end{array}$ & $\begin{array}{l}-0.161^{* * * *} \\
(5.421)\end{array}$ & $\begin{array}{l}-0.154^{* *} \\
(2.498)\end{array}$ \\
\hline 16-29 hours a week & $\begin{array}{l}-0.061 * * * \\
(2.724)\end{array}$ & $\begin{array}{l}-0.092 \\
(1.484)\end{array}$ & $\begin{array}{l}-0.037 \\
(1.477)\end{array}$ & $\begin{array}{l}-0.051 \\
(1.443)\end{array}$ \\
\hline$>48$ hours a week & $\begin{array}{l}-0.073^{* * * *} \\
(4.271)\end{array}$ & $\begin{array}{l}-0.085^{* * * *} \\
(4.277)\end{array}$ & $\begin{array}{l}-0.087 * * * \\
(2.887)\end{array}$ & $\begin{array}{l}-0.100 * * * \\
(4.331)\end{array}$ \\
\hline Female & $\begin{array}{l}-0.025 \\
(1.263)\end{array}$ & - & - & $\begin{array}{l}-0.025 \\
(1.104)\end{array}$ \\
\hline Log likelihood & $-11,263.1$ & $-5,376.1$ & $-5,661.0$ & $-1,399.5$ \\
\hline Model $\chi^{2}$ & $\begin{array}{l}2,729.3 \\
{[0.0000]}\end{array}$ & $\begin{array}{l}1,049.4 \\
{[0.0000]}\end{array}$ & $\begin{array}{l}1,927.3 \\
{[0.0000]}\end{array}$ & $\begin{array}{l}426.3 \\
{[0.0000]}\end{array}$ \\
\hline$N$ & 24,007 & 11,186 & 12,821 & 3,818 \\
\hline
\end{tabular}

Note: Obtained from probit regressions. $N$ is number of person-wave observations. Absolute $t$-values are reported in parentheses. The $t$-ratios are computed using standard errors that are robust to arbitrary forms of heteroskedasticity. See Table 2 for other definitions. The $\chi^{2}$ has 59 degrees of freedom (first column), 58 degrees of freedom (second and third columns) and 57 degrees of freedom (fourth column). All regressions also include: number of children by age group (two age groups: 0-4 years of age and 5-16 years of age), years of experience in part-time and full-time employment; ratio of local unemployment to local vacancies, and dummy variables for age groups (3 dummies), cohort of entry in the labour market (4), disability status, marital status (2), education (5), region of residence (6), house tenure (2), industry (9), occupation (8), sector (4), firm size (3), and a constant. The regression in the fourth column has only one firm-size dummy (as we restrict the sample to workers in firms with 500 employees or more).

*** significant at 0.01 level, ** significant at 0.05 level, * significant at 0.10 level 


\subsection{Unobserved heterogeneity}

The estimates in Tables 2 and 3 come from pooled (or crosssectional) probit models. In such models we control for a wide set of explanatory variables, particularly in the case of Britain (see Table A1). Yet, no matter how many variables are controlled for in a dataset, it is unlikely that we will be able to include all the relevant aspects of the worker's labour market history and preferences that are correlated with the propensity to work in a union-covered job, or all the relevant firmspecific practices that are associated with the probability to be a unioncovered organisation. It is, therefore, especially important to account for unobserved heterogeneity, since failure to do so may lead to biased coefficients (Heckman, 1981).

For this purpose, we exploit the longitudinal nature of the BHPS and ECL datasets and estimate a random effects (RE) maximumlikelihood probit model, which commonly assumes that the unobservables are uncorrelated with the observed individual characteristics. Although this assumption may not be true (e.g., unobserved ability and motivation are likely to be correlated with non-standard employment and other variables such as education and occupation; or cooperative practices between management and workers are likely to be correlated with firm size and industry), the RE probit model has a double compelling virtue: it efficiently accounts for the fact that, in panel data such as the BHPS and ECL, workers or firms are generally observed more than once, and it is computationally simple (Butler and Moffitt, 1982; Greene, 1997). We test the hypothesis of no cross-period correlation $(\rho=0)$ using a classical likelihood ratio test.

Tables 4 and 5 show the RE probit estimates for Spain and Britain, respectively. Again both tables report marginal effects, which have now been obtained following the procedure outlined in Arulampalam (1999). For both countries, the hypothesis of no cross-period correlation is clearly rejected even at high levels of statistical significance. This means that the pooled probit estimates, which are commonly used in the literature and shown in Tables 2 and 3, are biased. The estimated $\rho$ is around 0.76 in the ECL sample, and between 0.80 and 0.84 in the BHPS sample, revealing that the proportion of the total error variance accounted for by unobservable individual heterogeneity is three-quarters in Spain and around four-fifths in Britain. Comparing the results from the pooled probit estimates reported in Tables 2 and 3 and those found with the RE probit model, we find that the magnitude (and the statistical significance) of the effects is different with the marginal effects obtained from the pooled probit estimates being generally larger - in some cases up to two or times 
- than those from the RE probit model, suggesting an upward bias of the estimated cross-sectional coefficients.

Table 4: Testing for the presence of firm heterogeneity - Spain

\begin{tabular}{|c|c|c|c|}
\hline & \multicolumn{3}{|c|}{ Specification } \\
\hline & (1) & (2) & (3) \\
\hline Temporary employment & $\begin{array}{l}-0.003^{* * * *} \\
(19.81)\end{array}$ & $\begin{array}{l}-0.003^{* * *} \\
(21.02)\end{array}$ & $\begin{array}{l}-0.003^{* * *} \\
(20.66)\end{array}$ \\
\hline Part-time employment & $\begin{array}{l}-0.0002 \\
(1.05)\end{array}$ & $\begin{array}{l}-0.0001 \\
(0.63)\end{array}$ & $\begin{array}{l}-0.0002 \\
(1.04)\end{array}$ \\
\hline Overtime hours & $\begin{array}{l}-0.0000 \\
(0.66)\end{array}$ & - & $\begin{array}{l}-0.0000 \\
(0.03)\end{array}$ \\
\hline $\begin{array}{l}\text { Proportion of workers working } \\
\text { overtime }\end{array}$ & - & $\begin{array}{l}-0.0002 \\
(1.60)\end{array}$ & $\begin{array}{l}-0.0002 \\
(0.90)\end{array}$ \\
\hline $\begin{array}{l}\text { Overtime hours } \times \text { Proportion of } \\
\text { workers working overtime }\end{array}$ & - & - & $\begin{array}{l}-0.0006^{*} \\
(1.78)\end{array}$ \\
\hline Female & $\begin{array}{l}-0.004^{* * *} \\
(19.72)\end{array}$ & $\begin{array}{l}-0.004^{* * *} \\
(22.27)\end{array}$ & $\begin{array}{l}-0.004^{* * *} \\
(21.54)\end{array}$ \\
\hline$\rho$ & $\begin{array}{l}0.736^{* * *} \\
{[15,673.2]}\end{array}$ & $\begin{array}{l}0.758^{* * *} \\
{[15,582.8]}\end{array}$ & $\begin{array}{l}0.763^{* * *} \\
{[15,469.6]}\end{array}$ \\
\hline Log likelihood & $-8,482.7$ & $-8,460.7$ & $-8,462.4$ \\
\hline Model $\chi^{2}$ & $\begin{array}{l}2,436.9 \\
{[0.000]}\end{array}$ & $\begin{array}{l}2,424.4 \\
{[0.000]}\end{array}$ & $\begin{array}{l}2,538.9 \\
{[0.000]}\end{array}$ \\
\hline$N$ & 34,379 & & \\
\hline
\end{tabular}

Note: Obtained from random-effects probit regressions. The term $\rho$ is the proportion of total residuals variance attributable to the firm-specific random effects. The likelihood ratio test $\rho=0$ (which is asymptotically $\chi^{2}$ with one degree of freedom) is in square brackets. For other definitions and variables included in all regressions see note of Table 2 .

*** significant at 0.01 level, ** significant at 0.05 level, * significant at 0.10 level

For Spain, Table 4 shows that the negative association of plantlevel unionisation with temporary employment - found in Table 2 - is robust to the introduction of firm-specific unobservables. A one-percent increase in the proportion of termporary workers reduces the probability of a firm to have plant-level collective agreements by about 0.3 percentage points. As in Table 2, we also find that establishments with a greater proportion of female workers have a significantly lower probability of having firm-level union recognition. These are the correlations that remain significant after such unobservables are accounted for. Both parttime employment and overtime work (either in terms of hours or in terms of proportion of workers working overtime or both) never reach statistical significance at standard levels. 
Table 5: Testing for the presence of worker heterogeneity - Britain

\begin{tabular}{|c|c|c|c|}
\hline & Men & Women & $\begin{array}{c}\text { All workers (men } \\
\text { and women) in } \\
\text { firms with } 500+ \\
\text { employees }\end{array}$ \\
\hline Seasonal/casual & $\begin{array}{l}-0.006 \\
(0.360)\end{array}$ & $\begin{array}{l}-0.059^{* * * *} \\
(4.373)\end{array}$ & $\begin{array}{l}-0.063^{* *} \\
(2.403)\end{array}$ \\
\hline Fixed-term contract & $\begin{array}{l}-0.036^{*} \\
(1.842)\end{array}$ & $\begin{array}{l}-0.022 \\
(1.176)\end{array}$ & $\begin{array}{l}-0.184^{* * *} \\
(4.772)\end{array}$ \\
\hline$<16$ hours a week & $\begin{array}{l}-0.084^{* * *} \\
(3.702)\end{array}$ & $\begin{array}{l}-0.094^{* * * *} \\
(7.422)\end{array}$ & $\begin{array}{l}-0.111^{* * * *} \\
(4.418)\end{array}$ \\
\hline 16-29 hours a week & $\begin{array}{l}-0.042 \\
(1.598)\end{array}$ & $\begin{array}{l}-0.026^{* *} \\
(2.545)\end{array}$ & $\begin{array}{l}-0.038^{* * * *} \\
(3.393)\end{array}$ \\
\hline$>48$ hours a week & $\begin{array}{l}-0.011 \\
(1.265)\end{array}$ & $\begin{array}{l}-0.016 \\
(1.058)\end{array}$ & $\begin{array}{l}-0.018^{* *} \\
(1.974)\end{array}$ \\
\hline Female & - & - & $\begin{array}{l}-0.036^{* *} \\
(2.148)\end{array}$ \\
\hline$\rho$ & $\begin{array}{l}0.835^{* * *} \\
{[3,908.0]}\end{array}$ & $\begin{array}{l}0.802^{* * *} \\
{[3,663.9]}\end{array}$ & $\begin{array}{l}0.818^{* * *} \\
{[1,769.6]}\end{array}$ \\
\hline Log likelihood & $-3,422.1$ & $-3,829.1$ & $-1,826.2$ \\
\hline Model $\chi^{2}$ & $\begin{array}{l}1,222.6 \\
{[0.0000]}\end{array}$ & $\begin{array}{l}1,499.4 \\
{[0.0000]}\end{array}$ & $\begin{array}{l}735.1 \\
{[0.0000]}\end{array}$ \\
\hline$N$ & 11,186 & 12,821 & 3,818 \\
\hline
\end{tabular}

Note: Obtained from random-effects probit regressions. The term $\rho$ is the proportion of total residuals variance attributable to the worker-specific random effects. The likelihood ratio test $\rho=0$ (which is asymptotically $\chi^{2}$ with one degree of freedom) is in square brackets. For other definitions and variables included in the three specific regressions see the note to Table 3.

$* * *$ significant at 0.01 level, $* *$ significant at $0.05, *$ significant at 0.10

The picture that emerges from Table 5 for Britain is similar in some respects, although the quantitative effects are again larger in absolute value. Being in a mini-job reduces the probability of union coverage by 8-9 percentage points, but there is no statistical difference in the union coverage probability for men between those working 30-48 hours and those who work 16-29 hours a week. Furthermore, for women in seasonal/casual jobs, there is a reduction in the likelihood of union recognition by 6 points. For the subsample of workers who are employed in larger firms (with 500 or more employees) — whose comparability with the Spanish sample is presumably greater (see the last column in Table 5) — the largest effects emerge among seasonal/casual workers, workers on fixed-term contracts and workers in mini-jobs, who are respectively 6,18 and 11 percent less likely to be union covered. In line with the estimates in Table 3, also those in the other types of non-standard employment as well as female workers are found to have a lower probability of being covered by collective agreements, suggesting that the higher union 
coverage that characterises large firms in Britain is mainly concentrated on 'insiders' (Booth, 1995).

In sum, the results differ somewhat from what we found previously with cross-sectional probit models, but there remain similarities across countries. After accounting for individual unobserved heterogeneity, there is a significant and negative correlation between union coverage and temporary employment (the proportion of temporary workers in the case of Spain and being in seasonal/casual employment or in fixed-term contracts in the case of British workers). Being in a part-time job is also negatively correlated with union coverage in Britain (especially for women and for workers in large firms). This is the main finding which distinguishes the two countries, but, once more, it involves the way in which the extensive margin is related to unionisation. Interestingly, the intensive margin (at least in terms of high number of worked hours or overtime work) appears to have no effect on unionisation in either country (only in the case of workers in large firms a small negative effect is detected).

\subsection{Effects by industry}

As pointed out in the Introduction, Britain and Spain have experienced similar patterns of change in their macroeconomic aggregates during most of the 1990s. However, the two countries are characterised by different levels of economic activity and composition of the industrial structure. For example, in 1997, the primary sector (agriculture, forestry and fishery) represents only 1.5 percent of the gross value added of all industries for Britain, but its share is more than twice as large for Spain (3.3 percent); conversely, the share of market services is 54.5 percent in Britain and 51.8 percent in Spain (European Commission, 2001). These differences are mirrored in the labour market. In the same year, in Spain the employment share in the primary sector is 8.3 percent, in Britain it is 1.9 percent only; but the employment share in services is 61.8 percent in Spain and 71.2 percent in Britain (European Commission, 1999).

The probit estimates reported so far clearly show that the correlation between flexible employment over the intensive and extensive margins and union coverage is somewhat similar in Spain and Britain, despite their different employment protection legislation and labour market institutions. However, important differences in the way in which flexible employment and unionisation are correlated may be masked if we do not explicitly account for the different industrial structure of these countries. Stratifying workers or firms by broad industrial categories will probably reduce these sources of heterogeneity and allow us to identify the 
(possibly different) sectors that are responsible for the strongest associations in each economy.

In the ECL/BHPS samples, firms/workers are grouped into three industrial categories from the one-digit Standard Industrial Classification (SIC) system: 'manufacturing', which includes energy, extraction, metal goods and other manufacturing industries (SIC2-SIC4); 'services', which includes banking, finance, insurance and other services (SIC8-SIC9); and 'other', which includes construction, distribution, hotels, transport and communication (SIC5-SIC7). In the BHPS, analysis on the primary sector is not performed due to small sample sizes (see Table A1), whereas the ECL collects information only on non-agriculture industries. For each industrial sector, we have then estimated $\mathrm{RE}$ maximum-likelihood probit regressions, and, in the case of Britain, the regressions have been performed for men and women separately. The marginal effects of the flexible employment variables obtained from such regressions are reported in Tables 6 and 7 for Spain and Britain, respectively.

Table 6: Effects in broad industrial sectors - Spain

\begin{tabular}{llll}
\hline & Manufacturing & \multicolumn{1}{c}{ Services } & \multicolumn{1}{c}{ Other } \\
\hline Temporary employment & $-0.002^{* * *}$ & $-0.004^{* * *}$ & $-0.002^{* * *}$ \\
& $(5.06)$ & $(13.99)$ & $(13.57)$ \\
Part-time employment & 0.002 & $0.001^{*}$ & $-0.001^{* * *}$ \\
& $(1.37)$ & $(1.85)$ & $(3.41)$ \\
Overtime hours & 0.0007 & $0.001^{* * *}$ & 0.0000 \\
& $(1.56)$ & $(3.10)$ & $(0.19)$ \\
Proportion of workers working & 0.0002 & 0.0001 & $0.0005^{* *}$ \\
overtime & $(0.77)$ & $(0.18)$ & $(2.15)$ \\
Overtime hours $\times$ Proportion & 0.0000 & 0.0002 & $-0.003^{* * *}$ \\
workers working overtime & $(0.03)$ & $(0.15)$ & $(5.83)$ \\
Female & $-0.006^{* * *}$ & $-0.004^{* * *}$ & $-0.002^{* * *}$ \\
& $(15.47)$ & $(10.01)$ & $(6.42)$ \\
$\rho$ & $0.805^{* * *}$ & $0.805^{* * *}$ & $0.746^{* * *}$ \\
Log likelihood & {$[5,081.2]$} & {$[2,920.7]$} & {$[9,644.5]$} \\
Model $\chi^{2}$ & $-1,928.2$ & $-1,772.1$ & $-4,559.2$ \\
& 352.7 & 615.6 & 518.1 \\
$N$ & {$[0.000]$} & {$[0.0000]$} & {$[0.0000]$} \\
\hline
\end{tabular}

Note: Obtained from random-effects probit regressions. 'Manufacturing' includes: energy and water supplies; extraction of minerals, manufacturing of metals, mineral products and chemicals; metal goods, engineering and vehicles industries; other manufacturing industries. 'Services' includes: banking, finance, insurance, business services and leasing; other services (e.g., justice, police, school and higher education, medical practices, personal and domestic services). 'Other' includes: construction; distribution, hotel and catering (repairs); transport and communication. For other definitions and variables included in all regressions see notes of Tables 2 and 4. *** significant at 0.01 level, ** significant at 0.05 level, * significant at 0.10 level 
Table 6 shows that the negative relationship between unionisation and temporary employment found in Table 4 is a common feature across Spanish firms in all industries, being especially large in the case of firms in 'services'. ${ }^{30}$ The same is true for the correlation between union coverage and female employment; in this case, the relationship is particularly strong in 'manufacturing' industries. Interestingly, the stratification by industry allows us to uncover additional industry-specific effects, which could not be detected by the previous, more aggregated analysis. In particular, firms in 'other' (construction, distribution and transport) industries are characterised by a lower likelihood of plant-level unionisation not only along the extensive margin (part-time employment) but also along the intensive margin (through overtime work and the proportion of workers working overtime).

The evidence by industry is different for Britain. In the case of men, the negative effect of being in a mini-job (i.e., working less than 16 hours a week) found in Table 5 seems to be entirely driven by men employed in services (Table 7). Men working on non-standard contracts or non-standard hours in the other two sectors do not show any significant difference in their probability of being union covered compared to their regular counterparts. For women, the negative correlation between union coverage and working less than 16 hours a week emerges in all three industrial categories, and is strongest in the case of women in the manufacturing sector, whose probability of being union covered is reduced by 21 percentage points. Women in manufacturing and services (but not in the 'other' sector) are also less likely to be union covered if they are in halftime jobs. Finally, women in services who are on seasonal/casual contracts face a further reduction in their probability of union recognition by about 3.5 percentage points.

Thus, both countries show some similar relationships between unionisation and flexible (temporary) employment in the aggregate, with differences between the two countries that emerge when the data are sorted into broad industrial groups. On the one hand, the negative association of union coverage with temporary employment in Britain comes from employment relations in the service industries; similarly, although that relationship exists for all industries, in Spain it is particularly large in the case of firms in 'services'. On the other hand, in Britain, most of the action behind the negative correlation between union

\footnotetext{
30 The estimates in Table 6 are obtained from regressions which include the same variables as those included in specification (3) in Tables 2 and 4. The results obtained from the other two specifications are similar to those presented here, but are not shown for convenience. They can be obtained from the authors upon request.
} 
coverage and part-time employment involves employment relations in the service industries and, for women, in manufacturing; in the case of Spain, that correlation is strongly negative for 'other' industries, although it is non-existent in the aggregate.

Table 7: Effects in broad industrial sectors - Britain

\begin{tabular}{lllllll}
\hline & \multicolumn{3}{c}{ Men } & \multicolumn{3}{c}{ Women } \\
\hline & Manufact. & Services & \multicolumn{1}{c}{ Other } & Manufact. & Services & Other \\
\hline Seasonal/casual & -0.003 & $-0.050^{*}$ & 0.001 & -0.026 & $-0.035^{* *}$ & -0.026 \\
& $(0.084)$ & $(1.903)$ & $(0.051)$ & $(0.954)$ & $(2.033)$ & $(1.159)$ \\
Fixed-term contract & $-0.073^{*}$ & 0.020 & -0.024 & 0.056 & -0.010 & -0.032 \\
& $(1.804)$ & $(0.881)$ & $(0.653)$ & $(1.303)$ & $(0.528)$ & $(0.624)$ \\
$<16$ hours a week & 0.054 & $-0.136^{* * *}$ & -0.050 & $-0.212^{* * *}$ & $-0.116^{* * *}$ & $-0.037^{* *}$ \\
& $(0.528)$ & $(3.758)$ & $(1.402)$ & $(5.209)$ & $(7.412)$ & $(2.083)$ \\
16-29 hours a week & -0.067 & 0.001 & 0.020 & $-0.065^{* * *}$ & $-0.048^{* * *}$ & 0.003 \\
& $(1.243)$ & $(0.029)$ & $(0.541)$ & $(2.732)$ & $(3.774)$ & $(0.202)$ \\
$>48$ hours a week & -0.017 & -0.009 & -0.024 & 0.0003 & -0.003 & -0.033 \\
$\rho$ & $(1.327)$ & $(0.759)$ & $(1.370)$ & $(0.021)$ & $(0.159)$ & $(1.217)$ \\
& $0.884^{* * *}$ & $0.909^{* * *}$ & $0.847^{* * *}$ & $0.855^{* * *}$ & $0.850^{* * *}$ & $0.848^{* * *}$ \\
Log likelihood & {$[0.0000]$} & {$[0.0000]$} & {$[0.0000]$} & {$[0.0000]$} & {$[0.0000]$} & {$[0.0000]$} \\
Model $\chi^{2}$ & $-1,314$ & -882 & 1,068 & -586 & $-1,915$ & $-1,185$ \\
& 688.9 & 396.7 & 236.4 & 297.3 & 184.9 & 178.0 \\
$N$ & {$[0.0000]$} & {$[0.0000]$} & {$[0.0000]$} & {$[0.0001]$} & {$[0.0000]$} & {$[0.0000]$} \\
\hline
\end{tabular}

Note: Obtained from random-effects probit regressions. 'Manufacturing' includes: energy and water supplies; extraction of minerals, manufacturing of metals, mineral products and chemicals; metal goods, engineering and vehicles industries; other manufacturing industries. 'Services' includes: banking, finance, insurance, business services and leasing; other services (e.g., justice, police, school and higher education, medical practices, personal and domestic services). 'Other' includes: construction; distribution, hotel and catering (repairs); transport and communication. For other definitions and variables included in all regressions see notes of Tables 3 and 5.

*** significant at 0.01 level, ** significant at 0.05 level, * significant at 0.10 level

\section{Summary and conclusion}

This paper is the first attempt to analyse the relationship between unions and two components of the extensive and intensive margins of employment which have been increasingly associated with labour market flexibility - temporary employment and non-standard hours of work - in a comparative framework. In fact, in order to gain a better insight into this relationship, we compare the experiences of two economies, Spain and 
Britain, which are characterised by relatively different labour market structures and substantially different degrees of employment protection.

Despite such differences, these two countries show similar responses of unionisation to flexible employment. In particular, using data from the 1993-2002 ECL (Spain) and the 1991-1997 BHPS (Britain), we find that union recognition in Britain and firm-level union coverage in Spain do not respond to changes in the intensive margin, i.e., long hours of work and overtime hours (only in the case of workers in large firms a small negative effect is detected). We ought to emphasise that these similar results emerge in spite of the fact that overtime work is more prevalent amongst unionised firms in Spain, while long hours of work are more popular amongst non-union workers in Britain - at least in the case of men. Furthermore, during the sample period, both Spain and Britain moved through an economic recovery after the recession which hit both economies at the beginning of the 1990s. This finding therefore does not support the hypothesis that unionised firms find it easier than nonunionised firms to face small positive demand fluctuations by changing hours of work rather than the number of employees, because of greater fixed employment costs. Also, it does not support the hypothesis that workers who want to signal high levels of effort (via overtime work) pursue their careers solely on the basis of individual commitment rather than through collective bargaining.

Another common response in both countries is the one involving the relationship between unionisation and temporary employment: union coverage is negatively correlated with temporary employment. This finding corroborates the fact that in both countries temporary employment is significantly more prevalent amongst non-unionised firms or non-union workers. However, another aspect of the extensive margin, part-time employment, shows differing results for both countries: although it is again more concentrated in non-union firms and workers, is found to be negatively correlated with union coverage only in Britain. The fact that the proportion of part-timers is comparatively very low in Spain may drive that result.

We also find some differences and similarities between the two countries when the samples are stratified by industry. On the one hand, the negative association of union coverage with temporary employment in Britain comes from employment relations in the service industries; similarly, although that relationship is observed for all industries in Spain, it is especially marked in services. On the other hand, in Britain, most of the action behind the negative correlation between union coverage and part-time employment involves employment relations in the service industries and, for women, in manufacturing; but in Spain that correlation 
(which does not exist in the aggregate) is strongly negative for 'other' industries.

In any case, it should be pointed out that the potential for reverse causality may exist in our analysis. In Spain, while the proportion of workers in non-standard employment should affect the probability of having firm-level collective bargaining, it is also possible that having a firm-level collective bargaining may affect the proportion of workers in non-standard employment. Similarly, in Britain type of contract and working hours should influence the probability of being unionised, but also being unionised may have an effect on the type of contract held or the number of hours worked. Our estimates therefore should not be taken as causal effects; rather, they should be seen as suggestive correlations. In addition, results come from two datasets which are very different (for households in the case of Britain and for large firms in the case of Spain). It is clear that the BHPS and the ECL collect different data with distinct sampling procedures; these differences notwithstanding, they do provide adequate information to address the issues of interest here, although future research will have to make an effort to obtain and analyse more comparable data. Nonetheless, the information presented in this paper reveal substantial and unexpected similarities across the two countries.

Thus, is there a common tale of Spain and Britain, by which hours of work and temporary employment are linked to union recognition in a similar fashion in the two countries? The fact that, in the aggregate, most of the multivariate results are similar is not only surprising but also indicates that a common tale is conceivable. This finding is important, because it suggests that labour unions may organise specific groups of workers and provide means of resolution of the conflict of interest between employers and workers which are much the same across borders, regardless of country-specific structural differences. We believe that this is a powerful result that needs further investigation and additional comparative evidence.

A common-tale story is also important for another key reason. If in two as different economies as Britain and Spain the relationship between unions and labour market flexibility is so similar, labour market policies directly aimed at reducing costly employment protection rules or enhancing labour market flexibility may be inconsequential, at least in terms of (firm-level) union coverage. Furthermore, we ought to emphasise that the picture we have sketched in this paper is likely to change in the near future, as the repercussions of recent country-specific government legislation (especially, that related to minimum wages and temporary workers) and EU Directives for non-standard workers and part-timers come into force. Whether this leads to an increase or a decrease in union 
coverage of non-standard employees or of firms using large fractions of non-standard workers remains to be seen, since the various new provisions could act as either a substitute or a complement to the benefits that union organisation conveys to covered workers.

\section{References}

Arulampalam, W. (1999), "A Note on Estimated Coefficients in Random Effects Probit Models." Oxford Bulletin of Economics and Statistics, 61 (4), 597-602.

Becker, G. (1962), "Investment in Human Capital: A Theoretical Analysis." Journal of Political Economy, 70, 9-49.

Booth, A.L. (1995), The Economics of the Trade Union. Cambridge: Cambridge University Press.

Booth, A.L. and M. Francesconi (2003), "Union Coverage and Non" standard Work in Britain.” Oxford Economic Papers, 55(3), 383-416.

Booth, A.L., M. Francesconi and J. Frank (2002), "Temporary Jobs: Stepping Stones or Dead Ends?" Economic Journal, 112, F189-F213.

Brown, W. (1999), "Individualisation and Union Recognition in Britain in the 1990s." In S. Deery and R. Mitchell (eds.) Employment Relations: Individualisation and Union Exclusion. Sydney: Federation Press, 153170.

Brown, W. S. Deakin, D. Nash, S. Oxenbridge, C. Pratten and P. Ryan (2000), "The Future of Collectivism in Employment." ESRC Future of Work Bulletin, No. 2, August.

Butler, J. and R.A. Moffitt (1982), "A Computationally Efficient Quadrature Procedure for the One Factor Multinomial Probit Model.” Econometrica, 50, 761-764.

Cully, M. and S. Woodland (1998), "Trade Union Membership and Recognition 1996-97: An Analysis of Data from the Certification Officer and the LFS." Labour Market Trends, July, 353-364. 
Deery, D. and J. Walsh (1999), "The Decline of Collectivism? A Comparative Study of White-Collar Employees in Britain and Australia." British Journal of Industial Relations, 37(2), 245-269.

Department of Trade and Industry (2001), Fixed Term Work Public Consultation. URN 01/680, available at http://www.dti.gov.uk/er/fixed/contents.htm.

Dex, S. (1999), Families and the labour market. London: Family Policy Studies Centre for the Joseph Rowntree Foundation.

Dex, S. and A. McCulloch (1995), Flexible Employment in Britain: A Statistical Analysis. Equal Opportunity Commission, Research Discussion Series No. 15.

Disney, R., A. Gosling and S. Machin (1994), "British Unions in Decline: An Examination of the 1980s Fall in Trade Union Recognition." Industrial and Labor Relations Review, 48, 403-419.

Dolado, J.J., F. Felgueroso and J.F. Jimeno (1997) "The Effects of Minimum Bargained Wages on Eearnings: Evidence from Spain." European Economic Review, 41, 713-721.

Dolado, J.J., C. Garcia-Serrano and J.F. Jimeno (2002), "Drawing Lessons from the Boom of Temporary Jobs in Spain." Economic Journal, 112, F270-F295.

Dolado, J.J., F. Kramarz, S. Machin, A. Manning, D. Margolis and C. Teulings (1996), "The Economic Impact of Minimum Wages in Europe." Economic Policy, 23, 317-372.

Escobar, M. (1995), "Spain: Works Councils or Unions?", 153-188, in J. Rogers and W. Streek (eds.), Works Councils: Consultation, Representation, and Cooperation in Industrial Relations. Chicago: NBER-Chicago University Press.

European Commission (1999), Employment in Europe 1998. Employment and Social Affairs, Employment and European Social Fund. Luxembourg: Office for the Official Publications of the European Communities. 
European Commission (2001), Eurostat Yearbook: The Statistical Guide to Europe. Data 1989-99. Luxembourg: Office for the Official Publications of the European Communities.

Farber, H.S. and B. Western (2000), "Round Up the Usual Suspects: The Decline of Unions in the Private Sector, 1973-1998." Working Paper No. 437, Industrial Relations Section, Princeton University.

Fondazione Rodolfo De Benedetti (2000), "Appendix: Taking the Stock of Social Policy Reforms in Europe." In G. Bertola, T. Boeri and G. Nicoletti (eds.) Welfare and Employment in a United Europe. Cambridge, Mass.: MIT Press.

Freeman, R.B. and Medoff, J. (1979), "The Two Faces of Unionism." Public Interest, 57, 69-93.

Freeman, R.B. (1980), "The Exit-voice Tradeoff in the Labor Market: Unionism, Job Tenure, Quits, and Separations." Quarterly Journal of Economics, 94, 643-673.

García-Murcia, J., Gutiérrez-Palacios, R., and Rodríguez-Sañudo, F. (1995), "La Incidencia de los Criterios de Representatividad en la Configuración del Sistema Sindical Español." In J.J. Dolado and J.F. Jimeno (eds.), Estudios sobre el Funcionamiento del Mercado de Trabajo Español. Madrid: FEDEA.

Greene, W.H. (1997), Econometric Analysis (third edition), PrenticeHall International.

Hakim, C. (1997), "A Sociological Perspective on Part-Time Work." In H.-P. Blossfeld and C. Hakim (eds.) Between Equalization and Marginalization: Women Working Part-Time in Europe and the United States. Oxford: Oxford University Press.

Hamermesh, D. (1993), Labor Demand. Princeton: Princeton University Press.

Heckman, J.J. (1981), "Statistical Models for Discrete Panel Data." In C.F. Manski and D. McFadden (eds.) Structural Analysis of Discrete Data with Econometric Applications, Cambridge Ma: MIT Press, 114178. 
Heckman, J.J. (1993), "What Has Been Learned About Labor Supply in the Past Twenty Years?" American Economic Review Papers and Proceedings, 83(2), 116-121.

Heery, E., H. Conley, R. Delbridge and P. Stewart (2000), "Beyond the Enterprise? Trade Unions and the Representation of Contingent Workers." Unpublished manuscript, Cardiff Business School, October.

Hirschman, A. (1970), Exit, Voice, and Loyalty. Cambridge: Harvard University Press.

Iacovou, M. and R. Berthoud (2000), Parents and Employment. Department of Social Security, Research Report 107, London: Stationary Office.

Jimeno, J.F. (1992), "Las Implicaciones Macroeconómicas de la Negociación Colectiva: El Caso Español." Moneda y Crédito, 195, 223281.

Jimeno, J.F. and Toharia, L. (1993), "Spanish Labour Markets: Institutions and Outcomes", 299-322, in J. Hartog and J. Theeuwes (eds.), Labour Market Contracts and Institutions, Elsevier Science Publishers.

Landers, R.M., J.B. Rebitzer and L.J. Taylor (1996), "Rat Race Redux: Adverse Selection in the Determination of Work Hours in Law Firms." American Economic Review, 86(3), 329-248.

Lewis, R. (1991), "Reforming Industrial Relations: Law, Politics and Power." Oxford Review of Economic Policy, 7(1), 60-75.

Machin, S. (2000), "Union Decline in Britain." British Journal of Industrial Relations, 38(4), 631-645.

Neathey, F. and J. Arrowsmith (1999), Early Implementation of the Working Time Regulations. Interim Research Report for the Department of Trade and Industry, October.

Organisation for Economic Co-operation Development (1994, 1997, 1999, 2002), OECD Employment Outlook. Paris: OECD. 
Parsons, D.O. (1972), "Specific Human Capital: An Application to Quit Rates and Layoff Rates." Journal of Political Economy, 80, 1120-1143.

Storey, J. and N. Bacon (1993), "Individualism and Collectivism: Into the 1990s." International Journal of Human Resource Management, 4, 665-684. 


\section{Appendix}

Table A1: Definition and means of variables

\begin{tabular}{|c|c|c|c|c|}
\hline \multirow[b]{2}{*}{ Variable } & \multirow[b]{2}{*}{ Definition } & \multirow{2}{*}{$\begin{array}{c}\text { ECL } \\
\text { sample } \\
\text { (Spain) }\end{array}$} & \multicolumn{2}{|c|}{$\begin{array}{l}\text { BHPS sample } \\
\text { (Britain) }\end{array}$} \\
\hline & & & Men & $\begin{array}{c}\text { Wom } \\
\text { en }\end{array}$ \\
\hline Female & Proportion of female workers & 0.381 & & \\
\hline $\begin{array}{l}\text { Number of children } \\
<5 \text { years }\end{array}$ & $\begin{array}{l}\text { Number of dependent children aged } \\
\text { less than } 5 \text { in the household }\end{array}$ & & 0.186 & 0.131 \\
\hline $\begin{array}{l}\text { Number of children } 5^{-} \\
16\end{array}$ & $\begin{array}{l}\text { Number of dependent children aged } \\
5-16 \text { in the household }\end{array}$ & & 0.524 & 0.564 \\
\hline Part-time experience & $\begin{array}{l}\text { Part-time work experience since } \\
\text { labour market entry (years) }\end{array}$ & & 0.236 & 4.737 \\
\hline Full-time experience & $\begin{array}{l}\text { Full-time work experience since } \\
\text { labour market entry (years) }\end{array}$ & & 17.081 & $\begin{array}{l}10.17 \\
7\end{array}$ \\
\hline $\mathrm{U}-\mathrm{V}$ ratio & $\begin{array}{l}\text { Ratio of local unemployment stock } \\
\text { to local vacancy stock. The } \\
\text { geographic unit is } 306 \text { matched job } \\
\text { centres and travel-to-work areas } \\
\text { (source is National On-line } \\
\text { Manpower Information Service) }\end{array}$ & & 15.691 & $\begin{array}{l}15.53 \\
8\end{array}$ \\
\hline GDP change & Quarterly GDP change & 0.762 & & \\
\hline Trend1 (base) & Year 1993 & 0.085 & & \\
\hline Trend2 & Year 1994 & 0.086 & & \\
\hline Trend3 & Year 1995 & 0.107 & & \\
\hline Trend 4 & Year 1996 & 0.082 & & \\
\hline Trend5 & Year 1997 & 0.104 & & \\
\hline Trend6 & Year 1998 & 0.115 & & \\
\hline Trend7 & Year 1999 & 0.122 & & \\
\hline Trend8 & Year 2000 & 0.127 & & \\
\hline Trend9 & Year 2001 & 0.137 & & \\
\hline Trend10 & Year 2002 & 0.035 & & \\
\hline Age group: & & & & \\
\hline Age1 & Aged 25 or less & & 0.249 & 0.234 \\
\hline Age2 & Aged between 26 and 35 & & 0.326 & 0.301 \\
\hline Age3 (base) & Aged between 36 and 45 & & 0.259 & 0.267 \\
\hline Age4 & Aged between 46 and 60 & & 0.166 & 0.198 \\
\hline $\begin{array}{l}\text { No } \\
\text { (base) qualification }\end{array}$ & No educational qualification & & 0.141 & 0.168 \\
\hline Some qualification & $\begin{array}{l}\text { Some qualifications short of } \mathrm{O} \\
\text { level/GCSE }\end{array}$ & & 0.084 & 0.108 \\
\hline O level/GCSE & $\begin{array}{l}\text { Highest educational qualification is } \\
\text { one or more "Ordinary"-level } \\
\text { qualifications (later replaced by } \\
\text { General Certificate of Secondary } \\
\text { Education), taken at end of }\end{array}$ & & 0.210 & 0.282 \\
\hline
\end{tabular}




\begin{tabular}{|c|c|c|c|c|}
\hline & compulsory schooling at age 16 & & & \\
\hline A level & $\begin{array}{l}\text { Highest educational qualification is } \\
\text { one or more "Advanced"-level } \\
\text { qualifications, representing } \\
\text { university r entrance-level } \\
\text { qualification, taken typically at age } \\
18\end{array}$ & & 0.162 & 0.118 \\
\hline Vocational degree & Higher vocational degree & & 0.258 & 0.212 \\
\hline Higher qualification & University degree or above & & 0.145 & 0.112 \\
\hline Disabled & $\begin{array}{l}\text { Registered as disabled either with } \\
\text { social services or a green card }\end{array}$ & & 0.014 & 0.010 \\
\hline Firm size & $\begin{array}{l}\text { Average number of employees per } \\
\text { firm }\end{array}$ & 1,241 & & \\
\hline Size1-24 & $\begin{array}{l}\text { Firm size: fewer than } 25 \text { employees } \\
\text { at the establishment }\end{array}$ & & 0.261 & 0.385 \\
\hline Size25-99 & $\begin{array}{l}\text { Firm size: } 25-99 \text { employees at the } \\
\text { establishment }\end{array}$ & & 0.252 & 0.246 \\
\hline Size100-499 & $\begin{array}{l}\text { Firm size: } 100-499 \text { employees at the } \\
\text { establishment }\end{array}$ & & 0.286 & 0.223 \\
\hline Size 500+ (base) & $\begin{array}{l}\text { Firm size: } 500 \text { plus employees at the } \\
\text { establishment }\end{array}$ & & 0.201 & 0.146 \\
\hline Civil service & $\begin{array}{l}\text { Works in the civil service and } \\
\text { central government }\end{array}$ & & 0.049 & 0.039 \\
\hline Local government & $\begin{array}{l}\text { Works in the local government and } \\
\text { town halls }\end{array}$ & & 0.104 & 0.189 \\
\hline Other public sector & $\begin{array}{l}\text { Works in the NHS, higher } \\
\text { education, nationalised industry }\end{array}$ & & 0.059 & 0.109 \\
\hline Non-profit sector & $\begin{array}{l}\text { Works in non-profit organisation } \\
\text { (charities, co-operatives, etc.) }\end{array}$ & & 0.024 & 0.048 \\
\hline $\begin{array}{l}\text { Married or cohabiting } \\
\text { (base) }\end{array}$ & $\begin{array}{l}\text { Married or cohabiting at interview } \\
\text { date }\end{array}$ & & 0.679 & 0.704 \\
\hline Never married & Never married at interview date & & 0.272 & 0.198 \\
\hline Other marital status & $\begin{array}{l}\text { Separated, widow or divorced at } \\
\text { interview date }\end{array}$ & & 0.049 & 0.098 \\
\hline $\begin{array}{l}\text { Before } 1960 \text { s } \\
\text { (base) }\end{array}$ & $\begin{array}{l}\text { Entered the labour market before } \\
1961\end{array}$ & & 0.054 & 0.047 \\
\hline 1960s cohort & $\begin{array}{l}\text { Entered the labour market 1961- } \\
1970\end{array}$ & & 0.205 & 0.129 \\
\hline 1970s cohort & $\begin{array}{l}\text { Entered the labour market 1971- } \\
1980\end{array}$ & & 0.199 & 0.232 \\
\hline 1980s cohort & $\begin{array}{l}\text { Entered the labour market 1981- } \\
1990\end{array}$ & & 0.474 & 0.509 \\
\hline 1990s cohort & $\begin{array}{l}\text { Entered the labour market after } \\
1991\end{array}$ & & 0.068 & 0.083 \\
\hline Owner (base) & $\begin{array}{l}\text { Worker is house owner (outright or } \\
\text { with mortgage) }\end{array}$ & & 0.818 & 0.798 \\
\hline Social housing & $\begin{array}{l}\text { Worker lives in a local authority or } \\
\text { housing association type of } \\
\text { accommodation }\end{array}$ & & 0.099 & 0.125 \\
\hline
\end{tabular}




\begin{tabular}{|c|c|c|c|c|}
\hline Private rent & $\begin{array}{l}\text { Worker lives in a privately rented } \\
\text { accommodation }\end{array}$ & & 0.083 & 0.077 \\
\hline Primary (BHPS base) & Agriculture, forestry and fishing & & 0.032 & 0.018 \\
\hline Energy & Energy and water supplies & 0.038 & 0.034 & 0.007 \\
\hline Extract & $\begin{array}{l}\text { Extraction and manufacturing of } \\
\text { metals }\end{array}$ & 0.074 & 0.052 & 0.019 \\
\hline Metal & Metal goods and vehicles industries & 0.095 & 0.143 & 0.042 \\
\hline Other manufacturing & Other manufacturing industries & 0.069 & 0.125 & 0.070 \\
\hline Construction & Construction & 0.022 & 0.046 & 0.005 \\
\hline Distribution & Distribution, hotel and catering & 0.083 & 0.158 & 0.235 \\
\hline Transport & Transport and communication & 0.087 & 0.081 & 0.031 \\
\hline Banking & $\begin{array}{l}\text { Banking, finance insurance and } \\
\text { business }\end{array}$ & 0.246 & 0.120 & 0.126 \\
\hline $\begin{array}{l}\text { Other services (ECL } \\
\text { base) }\end{array}$ & Other services & 0.286 & 0.209 & 0.447 \\
\hline Strike activity & $\begin{array}{l}\text { Proportion of firms reporting } \\
\text { strike(s) during the quarter of } \\
\text { reference }\end{array}$ & 0.075 & & \\
\hline Region of residence: & Seven regional dummy variables & & & \\
\hline Greater London (base) & & & 0.093 & 0.092 \\
\hline $\begin{array}{l}\text { South East and South } \\
\text { West }\end{array}$ & & & 0.278 & 0.286 \\
\hline East Anglia and & & & 0.212 & 0.198 \\
\hline $\begin{array}{l}\text { Midlands } \\
\text { North West (including }\end{array}$ & & & 0.116 & 0.109 \\
\hline $\begin{array}{l}\text { Manchester) } \\
\text { North East }\end{array}$ & & & 0.162 & 0.158 \\
\hline Wales & & & 0.051 & 0.050 \\
\hline Scotland & & & 0.088 & 0.107 \\
\hline Occupation: & $\begin{array}{l}\text { Nine one-digit } \quad \text { Standard } \\
\text { Occupational Classification dummy } \\
\text { variables }\end{array}$ & & & \\
\hline Managerial & & & 0.165 & 0.084 \\
\hline Professional & & & 0.107 & 0.104 \\
\hline Technical occupations & & & 0.102 & 0.107 \\
\hline Clerical / secretarial & & & 0.096 & 0.293 \\
\hline Craft & & & 0.184 & 0.026 \\
\hline $\begin{array}{l}\text { Personal and } \\
\text { protective services }\end{array}$ & & & 0.067 & 0.143 \\
\hline Sales & & & 0.053 & 0.106 \\
\hline $\begin{array}{l}\text { Plant and machine } \\
\text { operatives }\end{array}$ & & & 0.147 & 0.039 \\
\hline $\begin{array}{l}\text { Other unskilled } \\
\text { occupations }\end{array}$ & & & 0.080 & 0.098 \\
\hline $\begin{array}{l}\text { Number of person- } \\
\text { wave observations }\end{array}$ & & & 11,186 & $\begin{array}{l}12,82 \\
1\end{array}$ \\
\hline $\begin{array}{l}\text { Number of firm- } \\
\text { quarter observations }\end{array}$ & & 34,379 & & \\
\hline
\end{tabular}

